\title{
Erratum to survival outcomes in prostate cancer patients with a prior cancer
}

\section{Editorial Office}

Translational Andrology and Urology

Correspondence to: Editorial Office. Translational Andrology and Urology. Email: tau@amepc.org.

Submitted Nov 05, 2021. Accepted for publication Nov 22, 2021.

doi: 10.21037/tau-2021-07

View this article at: https://dx.doi.org/10.21037/tau-2021-07

Erratum to: Transl Androl Urol 2021;10:741-53

In the article that appeared on Page: 741-753, Vol 10, No 2 (February 2021) Issue of the Translational Andrology and Urology (TAU) (1), the $\mathrm{P}$ value in Figure 3 was incorrect. The corrected Figure 3 appears below.

Click here to view the updated version of the article.

Open Access Statement: This is an Open Access article distributed in accordance with the Creative Commons AttributionNonCommercial-NoDerivs 4.0 International License (CC BY-NC-ND 4.0), which permits the non-commercial replication and distribution of the article with the strict proviso that no changes or edits are made and the original work is properly cited (including links to both the formal publication through the relevant DOI and the license). See: https://creativecommons.org/ licenses/by-nc-nd/4.0/. 

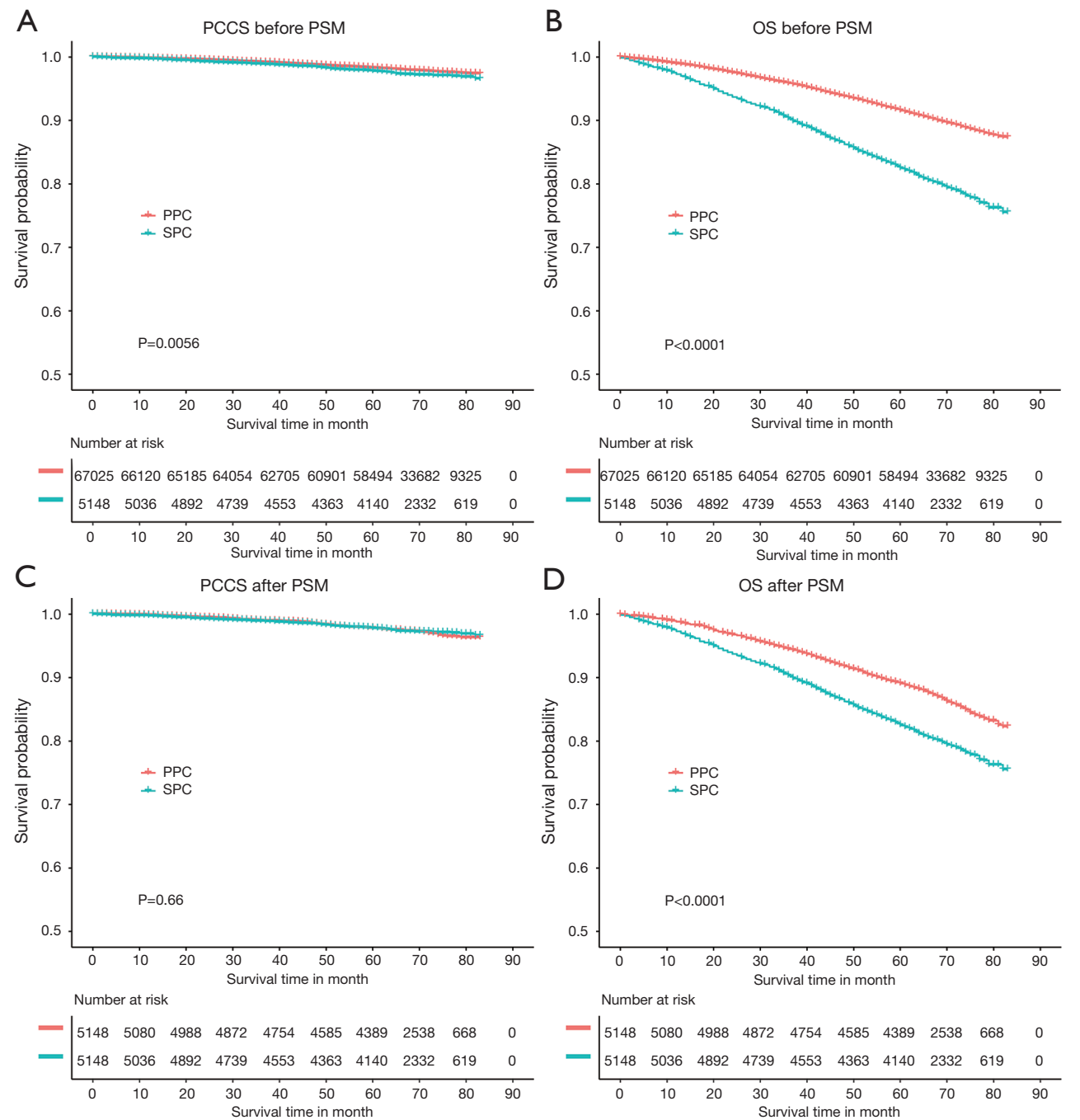

$$
\begin{aligned}
& \text { Number at risk }
\end{aligned}
$$

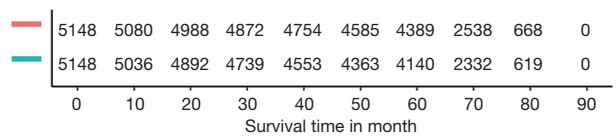

Figure 3 Kaplan-Meier survival curves of patients with prostate cancer as the second primary cancer or the prior cancer. (A,B) PCSS and overall survival before PSM; (C,D) PCSS and overall survival after PSM. PCSS, prostate cancer-specific survival; PSM, propensity score matching.

\section{References}

1. Zang Y, Qi F, Cheng Y, et al. Survival outcomes in prostate cancer patients with a prior cancer. Transl Androl Urol 2021;10:741-53.

Cite this article as: Editorial Office. Erratum to survival outcomes in prostate cancer patients with a prior cancer. Transl Androl Urol 2021;10(12):4431-4432. doi: 10.21037/tau-2021-07 